\title{
Koncept ontološkog tijela u prozama hrvatskih spisateljica prve polovice 20. stoljeća
}

Kornelija Kuvač-Levačić*

klevac@unizd.hr

Ana Vulelija***

avulelija@unizd.hr
UDK: 821.163.42-055.2“19“

141.319 .8

Izvorni zananstveni rad / Original scientific paper

Primljeno: 1. veljače 2017.

Prihvaćeno: 5. srpnja 2017.

Čitava povijest zapadne misli iskustvo tjelesnog, vezanog uz pojam žene $i$ ženskosti, vezivala je uz predodžbe podređenosti ili nadnaravne uzvišenosti, utemeljene na dualističkom konceptu tijelo/duša, koja sa stvarnim iskustvom bivanja u ženskom tijelu nije imala puno veze. Ne začuduje stoga činjenica da su se različiti feministički pokreti u drugoj polovici dvadesetog stoljeća usmjerili upravo na propitivanja tjelesnih iskustava žene u konkretnim društvenim zajednicama, no bez nastojanja oko iščitavanja moguće transcendentnosti tijela, skrenuvši time prema paradoksu produbljivanja dualizma. Hrvatske spisateljice već u prvoj polovici 20. stoljeća tematiku tijela i tjelesnosti prepoznale su kao potencijalnu u izgradnji svojih angažiranih književnih tekstova. Problematika kojom će se ovaj rad primarno baviti - a koja svoj okvir dobiva najprije u prikazu okolnosti u kojima su stvarale hrvatske spisateljice na korelaciji suprotnih pojmova um/tijelo, muško/žensko, gdje se, prema teoretičarki feminizma i korporalnosti Elizabeth Grosz, reprezentacija muškarca povezuje s umom, a žene s tijelom (1994.) - odnosi se na prikaze tijela i tjelesnosti u književnim djelima onih autorica koje su ovu tematiku smjestile u središte svog književnog interesa. Pokazat ćemo da te autorice (Zofka Kveder, Mara Ivančan, Mara Švel-Gamiršek) žensko tijelo nastoje reinterpretirati tako da se ono izdiže iznad navedenih, kulturalno prihvaćenih binarnih opreka. Ispitat će se mogućnost iščitavanja transcendentnog, ontološkog, odnosno filozofskog tijela u njihovim tekstovima. Filozofsko tijelo čini jedan od najvažnijih problema suvremene filozofije, prema teoriji filozofa Jean-Lucea Nancyja, koji se posebno bavio razbijanjem binarne

\footnotetext{
* Izv. prof. dr. sc. Kornelija Kuvač-Levačić, Sveučilište u Zadru, Odjel za kroatistiku i slavistiku, Odsjek za hrvatski jezik i književnost, Obala kralja Petra Krešimira IV., HR-23000 Zadar.

**Ana Vulelija, mag. philol. croat., Sveučilište u Zadru, Odjel za kroatistiku i slavistiku, Odsjek za hrvatski jezik i književnost, Obala kralja Petra Krešimira IV., HR-23000 Zadar.
} 
opozicije duh/tijelo i davanjem novih značenja tijelu. Korpus tekstova obradenih u ovom radu činit će: zbirka fragmenata Misterij žene hrvatsko-slovenskočeške spisateljice Zofke Kveder, zatim roman ili duža pripovijest Čudnovata priča Mare Ivančan $i$, na koncu, zbirka pripovijedaka Mare Švel-Gamiršek Portreti nepoznatih žena. Rad će odgovoriti na pitanje jesu li spomenute književnice ponudile drukčiju predodžbu tijela od one koja im se, kao podređenim članovima društva, pripisivala (žensko tijelo koje kao takvo ne može biti u vezi $s$ kategorijama razum/spiritualno jer je vođeno isključivo nagonima) i one koju su nekoliko desetljeća kasnije ponudile feminističke teorije drugog vala (gdje se tijelo koncipira dominantno kao materijalno iskustvo i kojem se, kao takvom, ne otvaraju mogućnosti za pripisivanje transcendentnosti).

Ključne riječi: ontološko tijelo, dodir, hrvatske spisateljice, personalistička vizija tijela, oprostoravanje.

\section{Uvod}

Početak 20. stoljeća u hrvatskoj književnosti obilježen je prodorom novih, modernih tema, tehnika i postupaka te ujedno i naglim porastom broja žena koje se posvećuju književnom radu (Adela Milčinović, Zofka Kveder, Zdenka Marković, Ivana Brlić Mažuranić, Marija Jurić Zagorka, Marija Kumičić, Marija Tomšić-Im, Štefa Jurkić, Milka Pogačić i mnoge druge). ${ }^{1}$ Brojne su studije, a osobito ona Dubravke Oraić-Tolić (Muška moderna, ženska postmoderna) pokazale da su se kultura i književnost moderne još uvelike razvijale na binarnim oprekama um-bezumlje, subjekt-objekt, proizvodnja-potrošnja ${ }^{2}$ pri čemu se uz ženu vezala pozicija drugog člana pa su kulturalne prakse bile obilježene dominacijom muškaraca. ${ }^{3} \mathrm{Uz}$ ovakvu neodobravajuću pozadinu, obilježene predrasudama i stereotipima, stvaraju hrvatske književnice prve polovice 20. stoljeća, čiji tekstovi već samim time nose oznaku feminističkih. ${ }^{4}$ Žensko tijelo,

${ }^{1}$ Usp. Dunja DETONI-DUJMIĆ, Ljepša polovica književnosti, Zagreb, Matica hrvatska, 1998, 20-29.

${ }^{2}$ Dubravka ORAIĆ-TOLIĆ, Muška moderna i ženska postmoderna, Zagreb, Naklada Ljevak, 2005, 87-88.

3 Isto, 70.

${ }^{4}$ Pojam feministički tekst javlja se uz još dva srodna pojma: feminilni i ženski tekst. Pojmove detaljno objašnjava Elizabeth Grosz u knjizi Prostor, vrijeme i perverzija (1995), i Toril Moi u tekstu Feministička književna kritika (1989), a donosi ih Jasmina Lukić u svom članku Tijelo $i$ tekst u feminističkoj vizuri. Ženski tekstovi se određuju kao oni koje pišu žene, uglavnom za žene; feminilni kao oni koji se pišu sa stajališta ženskog iskustva, a oblikuju se »u relaciji spram normi modela ženskosti kakav je u danom vremenu uobličen kao prihvaćeni kulturni konstrukt«; dok feministički »samosvjesno dovode u pitanje metode, objekte, ciljeve ili principe glavnog toka patrijarhalnih kanona« [Elizabeth GROSZ, Space, Time, Perversion, New York London, Routledge, 1995, 11, citat u: Jasmina LUKIĆ, Tijelo i tekst u feminističkoj vizuri, Treća, 3 (2001) (i.e. 2002) 1-2, 238], odnosno oni koji »nose u sebi jasnu političku poziciju, osviješteni otpor prema patrijarhatu « [Toril MOI, Feminist, female, Feminine, u: C. Belsey, J. Moore (ur.) 
koje, prema Foucaultu, čini »krucijalno mjesto iskazivanja i uspostave moći«, ${ }^{5}$ postaje upijajuća podloga diskursa koji proizvode nosioci moći, stanovitog znanja, u ovom slučaju - književnici i kritičari hrvatske književnosti prve polovice 20. stoljeća. Upisivanje ženskog tijela i tjelesnosti bit će tiha borba spisateljica iz pozicije $»$ Drugoga.$^{6}$

Problematika kojom će se baviti ovaj rad dotiče se korelacije pojmova um/ tijelo, muško/žensko gdje se, prema Elizabeth Grosz »reprezentacija muškarca povezuje s umom, a žene s tijelom «.7 Ispitat će se mogućnost iščitavanja ontološkog tijela ${ }^{8} \mathrm{u}$ tekstovima hrvatskih spisateljica na teoretskim postavkama filozofa Jean-Luca Nancyja (koje je u posebnom radu obrazložio i kontekstualizirao Bernard Harbaš). Iz Nancyevih studija za ovaj rad su posebno značajne ideje o razbijanju dualizma duh/tijelo i davanje novih značenja tijelu kroz zamisao njegova pluraliteta. ${ }^{9}$ To će proširiti naše spoznaje o tjelesnosti kao konstitutivnom elementu poetika promatranih autorica, ali i dati nove perspektive istraživanja toga predmeta u hrvatskoj književnosti uopće.

Prije nego što se usredotočimo na primarne izvore koji su temeljna podloga ovoga rada -književne tekstove spisateljica: Zofke Kveder, Mare Ivančan i Mare Švel-Gamiršek - potrebno je prikazati različita shvaćanja pojmova tijelo i tjelesnost kroz nekoliko povijesnih i suvremenih teorija (filozofskih, feminističkih, teoloških, antropoloških) da bismo razumjeli ishodišta stereotipnih poimanja, potom feminističke teorijske reakcije kao odgovora na stereotipne predodžbe tijela u zapadnoj kulturi, te suvremenije koncepte u humanističkim znanostima. Postavljamo pitanje: Može li se tijelo razmatrati na transcendentnoj razini i može li takav koncept činiti novu teorijsku podlogu u proučavanju tijela i tjelesnosti kao teme u književnosti?

The feminist Reader, Cambridge - Oxford, Basil Blackwell, 1989, 117-124, citat u: Lukić, nav. dj., 239]. Hrvatske književnice samim time što pišu i sudjeluju u društveno-kulturnom životu koji je trebao biti rezerviran samo za muškarce, pokazuju otpor prema predodžbama žene koje je imalo tadašnje patrijarhalno društvo, a koje su jasno prikazane kroz otpor kritičara i pisaca prema »ženskom« pisanju.

5 Belma BEĆIRBAŠIĆ, Tijelo, ženskost, moć, Zagreb, Synopsis, 2011, 82.

${ }^{6} \mathrm{O}$ istinitosti takve tvrdnje govori i mišljenje Ivana Gorana Kovačića o novelističkom radu Mile Miholjević, objavljeno u Novostima 1940. godine: »Kad netko ne bi znao da je pisac novela Mati i Zalog žena, postao bi bez ikakvih predrasuda njegov iskren štovalac« (Ljerka MATUTINOVIĆ, Predgovor, u: Jagoda TRUHELKA, Verka ŠKURLA-ILIJIĆ, Dora PFANOVA, Mila MIHOLJEVIĆ, Mara ŠVEL-GAMIRŠEK, Izabrana djela, Zagreb, Zora - Matica hrvatska, 1970, 270).

7 Elizabeth GROSZ, Preoblikovanje tijela, Treća, 4 (2002) 1, 6-25, 6.

8 »Jean-Luc Nancy će na tragu kršćanskog naslijeđa i fenomenološke filozofije (naročito Heideggerove i Merleau-Pontyeve misli) postaviti pitanje tjelesnog dodira kao izvornog kontakta. Nancy će otvoriti temu stanovite ontologije tijela, tijela kao temelja naše egzistencije. Ta ontologija jest ontologija mnoštva i sadržana je uvijek u onom »s(a)« bitka« [Bernard HARBAŠ, Tijela zajednice, Filozofska istraživanja, 28 (2008) 110, 435-440, 435].

9 »Ne možemo govoriti o tijelu, nego o tijelima i tjelesnosti. Francuski filozof ističe primat pluraliteta tijela, jer samo u zajednici, putem dodira kao izvornoga kontakta, konstituira se smisao. Tijelo ima ontološki status. Nancy u djelu Corpus piše o tijelu kao bitku egzistencije « (isto; usp. Jean-Luc NANCY, Corpus, New York, Fordham University Press, 2008, 136-139). 


\section{Pogled u teorije tijela - od dualizma duh/tijelo, preko feminizma do transcendentnosti tijela}

Godine 1994. istaknuta feministkinja, koja se posebno bavila tematikom korporalnosti u feminističkim teorijama, Elizabeth Grosz, napisala je da je »tijelo $u$ konceptualnom smislu još uvijek slijepa pjega u razmišljanjima ne samo glavnih struja zapadne filozofije nego i suvremene feminističke teorije « ${ }^{10} \mathrm{Su}-$ vremenim teorijama toga vremena zamjerila je što sva svoja promišljanja o tijelu i tjelesnosti temelje na suprotstavljanju filozofskim stajalištima koja »ljudski subjekt gledaju kao da je napravljen od dihotomno suprotnih karakteristika: uma i tijela, misli i protežnosti, razuma i strasti, psihologije i biologije ${ }^{11} \mathrm{E}$. Grosz se time kritički postavila prema onim smjerovima feminizma (posebice egalitarnom) koji se odriču bioloških specifičnosti ženskog tijela (svih njegovih tjelesnih ciklusa) i tako odlaze u drugu krajnost samo zato što su patrijarhalni sustavi ulogu žene sveli na seksualnost i reprodukciju. ${ }^{12}$ Začetke patrijarhalnih stavova Grosz vidi u povijesnom razvoju filozofije koja je »kao disciplina potajice isključila ženskost, a time u krajnjoj liniji i ženu iz svojih načina razmišljanja time što uvijek implicitno koristi isti kôd za ženskost i bezumnost kakva se vezuje uz tijelo «. ${ }^{13}$ Uz ženskost i ženstvenost se usko povezuju pojmovi kao »nestabilne, nepovjerljive, temperamentne karakteristike: nježan, srdačan, odan, senzitivan, stidljiv, suosjećajan, emotivan, senzualan, zavodljiv, izazovan, umiljat itd. ${ }^{14}$

Temelj patrijarhalnog pogleda na ženu konstruira se još u antičkoj Grčkoj, sa slavnom Platonovom odrednicom da je tijelo tamnica duše, odnosno razuma i uma. Platonova shvaćanja produbljuje Aristotel koji obrazlaže da je tijelo materija koju nudi majka, a otac je onaj koji toj materiji daje formu, oblik i obrise. U Aristotelovo doba poželjne karakteristike za ženu bile su šutljivost i čednost, a za muškarca, ženama nedostupne: muževnost, snaga i pamet. ${ }^{15}$ Spajanje požude i tijela, odnosno grijeha i tijela, pa onda odvajanje kategorija tijela i duha bit će polazište srednjovjekovnog doživljaja čovjeka. Jacques LeGoff, koji se posebno bavio srednjovjekovnim tijelom, naglašava upravo seksualni aspekt tijela $u$ kojem je kulminiralo "gnušanje od tijela«. Srednjovjekovni čovjek je u tjelesnim manama i bolestima vidio ostvarenje grijeha, a u tijelu ništa drugo osim truleži. ${ }^{16}$ LeGoff također ističe da je u srednjovjekovlju »vrhunac odvratnosti prema

\footnotetext{
${ }^{10}$ Grosz, nav. dj., 6.

${ }^{11}$ Isto, 6.

${ }^{12}$ Isto, 16.

${ }^{13}$ Isto, 7.

${ }^{14}$ Toril MOI, Seks, gender and the body, Oxford University Press, 2005, 56, citat u: Bećirbašić, nav. dj., 46.

${ }^{15}$ Prema: Branka GALIĆ, Ženska tijela, reprodukcija i društvena stigmatizacija žena, Kruh i ruže, 30 (2006) 23.

${ }^{16}$ Jacques LeGOFF, Srednjovjekovni imaginarij, Zagreb, Antibarbarus, 1993, 132.
} 
tijelu i seksu « upravo »u ženskom tijelu«. ${ }^{17}$ Jaz između duha i tijela, aktivnog i pasivnog, muškog i ženskog produbljuje se i utvrđuje s Descartesovom filozofijom u 17. stoljeću. »Dualizam« koji donosi jest »pretpostavka da postoje dvije različite, međusobno isključive i međusobno iscrpive supstance, um i tijelo, od kojih svaka boravi u svojoj vlastitoj samostalnoj sferi«. ${ }^{18}$

Prema Mihailu Bahtinu, za nov tjelesni kanon u književnosti (koji traje posljednja četiri stoljeća), pokraj svih njegovih povijesnih i žanrovskih varijacija, karakteristično je potpuno gotovo, završeno, strogo ograničeno, zatvoreno, nepomiješano i individualno-izražajno tijelo. Zatvorena površina tijela dobiva osnovno značenje kao granica individualnosti koja se ne sjedinjava s drugim tijelima ni sa svijetom. ${ }^{19}$ Otvoreno tijelo, koje je, između ostaloga, trudno, rađa ili doji, dakle koje živi na granicama između sebe i svijeta ili starog i novog tijela, svoga i tuđeg tijela, pripada Bahtinovu tzv. grotesknom modelu tijela u čijem su životu osnovna zbivanja činovi tjelesne drame gdje se početak i kraj života neraskidivo povezuju. Takav modus prikazivanja tjelesnog života, vladao je u umjetnosti i usmenom stvaralaštvu tisućama godina, da bi u posljednja četiri stoljeća službeni i književni govor novog tjelesnog kanona stavio zabranu na sve što je u vezi s oplođivanjem, trudnoćom, porođajem i sl., odnosno na sve što je povezano s nepotpunošću i nezavršenošću tijela i njegovim unutartjelesnim životom..$^{20} \mathrm{U}$ sliku toga grotesknog, otvorenog tijela osobito su se uklapala specifična iskustva ženske tjelesnosti (trudnoća, porođaj, dojenje itd.), o čemu je pisala npr. Iris Marion Young. ${ }^{21}$

Prikazana uporna sputavanja i uokviravanja ženskosti tijekom povijesti, ${ }^{22}$ nametanje drugosti, rodnih uloga, definiranja ženskosti od strane drugoga ${ }^{23} \mathrm{i}$ »kodiranje ženstvenosti tjelesnošću $\aleph^{24}$ doveli su do podizanja glasa žena i stvaranja ženskih (feminističkih) pokreta. Feministkinje je Grosz podijelila u tri kategorije.

U prvoj kategoriji promatra dvije struje. Feministkinje prve struje, među kojima je vodeća Simone de Beauvoir, uglavnom su imale negativan stav o ženskom tijelu jer ono svojim biološkim naginjanjem rađanju ograničava žene $u$

\footnotetext{
${ }^{17}$ Isto.

${ }^{18}$ Grosz, nav. dj., 9.

${ }^{19}$ Mihail BAHTIN, Stvaralaštvo Fransoa Reblea i narodna kultura srednjega vijeka i renesanse, Beograd, Nolit, 1978, 336.

${ }^{20}$ Prema: isto, 334-337.

${ }^{21}$ Usp. Iris Marion YOUNG, Trudnička tjelesnost, Subjektivnost i otuđenje, Filozofska istraživanja, 15 (1995) 3, 511-524.

${ }_{22}$ Prema: Lynda NEAD, Uokvirivanje ženskog tijela, Treća, 4 (2002) 1, 160.

${ }^{23}$ Linda Nead navodi da je na kreiranje mišljenja zapadne kulture o ženskosti i ženstvenom utjecalo gotovo kanonizirano Aristotelovo razmišljanje da su glavni oblici ljepote red, simetrija i konačnost (Nead 2002, 162). Drugim riječima, žena im je morala »udovoljavati« da bi bila lijepa i poželjna - a upravo su to osobine koje joj je društvo tijekom cijele (muške) povijesti nametalo (ovdje se posebice misli na različita književna djela, primjerice renesansna, koja veličaju ljepotu žene).

${ }^{24}$ Grosz, nav. dj., 15.
} 
ravnopravnom sudjelovanju u društvenom i kulturnom životu dosad rezerviranom pretežito za muškarce, dok su feministkinje druge struje $u$ »ženskom tijelu i iskustvu« vidjele mogućnost »specijalnog uvida, kakav muškarcima nedostaje ${ }^{25}$

Feministkinje prve kategorije upale su u zamku koju je nametnulo patrijarhalno društvo: žensko tijelo je prepreka postizanju ravnopravnosti i stoga ga se treba nadići (u isto vrijeme muškarci ne vide svoje tijelo kao prepreku). ${ }^{26}$ Negiranje činjenice da je žensko tijelo u svojoj biti stvaralačko, dovodi do novih zaziranja od tijela i granica koje se tijelu nameću te ometaju realan i pravedan pristup kroz različita motrišta. Ovakav feminizam, iako ga dijeli po drukčijim kriterijima, Anthony Giddens naziva radikalnim. ${ }^{27}$

Druga kategorija feministkinja, prema E. Grosz (Julia Kristeva, Michele Barrett, Nancy Chodorow i dr.) ima mnogo pozitivniji stav prema tijelu usmjerene su prema izjednačavanju i muških i ženskih tijela kroz društvenu reorganizaciju, odgajanje djece i socijalizaciju, što će za posljedicu imati neutraliziranje seksualno specifičnog tijela. Slažu se u ideji da problem nije u biološkoj podređenosti ženskih tijela, već u značenju koje je tijelu »dao i organizirao društveni sustav«, te im je stoga cilj »minimizirati biološke razlike i opskrbiti ih različitim kulturnim značenjima i vrijednostima . ${ }^{28}$

Treća kategorija, koju predstavljaju Luce Irigaray, Judith Butler, Jane Gallop i druge, tijelo doživljava ključnim »u razumijevanju ženine psihičke i društvene egzistencije «. ${ }^{29}$ Predmet njihova promatranja jest živo tijelo koje vide »kao politički, društveni, kulturni objekt par exellence, a ne kao proizvod sirove, pasivne prirode civilizirane, preopterećene i ulaštene kulturom $«{ }^{30}$ One priznaju i uvažavaju stvarne razlike među spolovima koje se ne mogu poreći, ali sasvim neopravdano, smatra Grosz, "potkopavaju razlike između spola i roda ", ${ }^{31}$ odnosno rodno nametnutih uloga. Kao što je na početku ovoga poglavlja naznačeno, Grosz je feministkinjama zamjerila što viziju tijela opet temelje na nametnutim patrijarhalnim doživljavanjima tijela kao »drugog«, pa svojim idejama ravnopravnost žele postići negiranjem tijela, izjednačavanjem muškog i ženskog tijela i potkopavanjem bioloških razlika. Iako su »feminističke teoretičarke kritizirale dihotomiju uma i tijela i intelektualno obezvređivanje tijela «, ${ }^{32}$ njihove ideje tek su preoblikovane ideje iz prikazane povijesti filozofije koja teorije o tijelu temelji na dualizmima duša/tijelo, vlastito/tuđe i sl.

\footnotetext{
${ }^{25}$ Isto, 16.

${ }^{26}$ Usp. isto, 17.

${ }^{27}$ Prema: Anthony GIDDENS, Sociologija, Zagreb, Nakladni zavod Globus, 2007, 115.

${ }^{28}$ Grosz, nav. dj., 18.

${ }^{29}$ Isto.

${ }^{30}$ Isto.

${ }^{31}$ Isto.

${ }^{32}$ Susan WENDELL, Feminizam, tjelesna nesposobnost i transcendentnost tijela, Treća, 4 (2002) $1,196$.
} 
Naime, u feminističkim teorijama, u njihovim borbama za ravnopravnost ženskog tijela, prema Susan Wendell, dogodio se znatan »propust«. Iako su se, kako je spomenuto, borile protiv dihotomije uma i tijela, sasvim su odbacile ideju o transcendentnosti, odnosno spiritualnosti tijela, jer su »smatrale da te kategorije potječu iz filozofija i/ili religija koje umanjuju vrijednost tijela (posebice ženskih tijela) i tjelesnog iskustva ${ }^{33}$ Zbog toga što je zapadnjačka tradicija obezvrijedila tijelo, posebice žensko tijelo, i pridodala mu negativne konotacije, feministički pokreti su se usmjerili isključivo na tjelesnost, odnosno na »nadvladavanje ženskoga društvenog i kulturnog otuđenja od naših vlastitih tijela« te se »feministički diskurs o tjelesnim iskustvima usredotočio na seksualnost, promjene u mjesečnim ciklusima, trudnoću, rađanje i majčinstvo «. ${ }^{34}$ Ispostavilo se da je borba protiv temeline opozicije duh/tijelo ostala samo teorijska i da se sve svelo samo na borbu za ravnopravnost tijela. Wendell zaključuje da je:

»(...) feminističko bavljenje otuđenjem od tijela i ženskim tjelesnim razlikama prema muškarcima unutar feminističke teorije stvorilo nerealnu sliku našega odnosa prema našim tijelima. $S$ jedne strane prešutno se vjeruje da bi naš doživljaj vlastitog tijela bio uglavnom ugodan i vrijedan kada bismo samo stvorili društvenu pravednost i nadvladali naše kulturno otuđenje od tijela.« « ${ }^{35}$

Usmjeravanje isključivo na tijelo, negiranje ili potiskivanje njegove transcendentnosti, iz očišta kršćanske antropologije, primjerice, negiranje je »cjelovitog gledanja na čovjeka«, s obzirom da baš u tijelu tražimo »dinamizme čovjekovih želja, njegov duh, njegovu narav i kulturu «. ${ }^{36}$ Carlo Caffarra u svom istraživanju o muškom i ženskom tijelu utvrđuje da »tijelo i tjelesnost spadaju $\mathrm{u}$ čovjekovu cjelovitost - integrum humanum, premda je ta cjelovitost danas veoma ugrožena djelomičnim poimanjem čovjeka i njegove tjelesnosti«. ${ }^{37}$ Iako je kršćanska povijest, posebice srednjovjekovna, tijelo obilježavala kao izvorište grijeha, nove teološke studije te filozofska i svetopisamska antropologija, primjerice, pojam tijela i tjelesnosti vide kao nešto »što čovjek jest«, a ne »što ima«, odnosno tijelo sagledaju kroz tri osnovne dimenzije: tjelesnost, kozmičnost i biologiju. U ovom kontekstu tjelesnost je »konstitutiv čovjekove ljudske opstojnosti, nositelj ljudske osobne jedinstvenosti« kakva se odnosi na njegovu nutarnju posebnost, na ono po čemu on »jest« i na odnose s drugima te ona niječe bilo kakav dualizam duh/tijelo.

Osim tjelesnosti ističe se kozmičnost tijela - upućenost tijela u prostoru na druga tijela, preko čega se »ostvaruje sebe, ostvarujući zajedništvo «. ${ }^{38}$ Odnos s

\footnotetext{
${ }^{33}$ Isto.

${ }^{34}$ Wendell, nav. dj., 197.

${ }^{35}$ Isto, 199.

${ }^{36}$ Luka TOMAŠEVIĆ, Teologija tijela i tjelesnosti, www.franjevci-split.hr/index.php?option= com_content\&view=article\&id=4176\&Itemid=14 (25.01.2017).

${ }^{37}$ Prema: Carlo CAFFARRA, Opći uvod; Ivan Pavao II., Muško $i$ žensko stvori ih. Kateheze o ljudskoj ljubavi, sv. I, Split, Verbum, 2012, 12, citat u: Tomašević, Teologija tijela i tjelesnosti...

${ }^{38}$ Tomašević, Teologija tijela i tjelesnosti...
} 
drugima, svrstavanje među druge, prema nekim personalističkim teorijama ${ }^{39}$ nužan je za svakog čovjeka, jer je svaki čovjek dio zajednice. Međutim »čovjek kao osoba u sebi posjeduje život, dobra i vrednote koje nadilaze taj odnos podvrgnutosti« i koje mu daju pravo na poziv, unutarnji vlastiti život i slobo$\mathrm{du} .{ }^{40}$ Nema dakle riječi o gubitku individualnosti kad se čovjeka promatra u zajedništvu. Temelj čovjekove slobode je njegova »duhovna narav ${ }^{41}$ odnosno njegovo tijelo ukoliko se čovjeka promatra kroz personalističku, cjelovitu viziju o čovjeku kao spoju duše i tijela. Andrea Zlatar u svojoj studiji Tekst, tijelo, trauma govori o nužnosti potrage za slobodom kad su u pitanju »različiti«, »obespravljeni«, te prema Kierkegaardu, donosi postavku da sloboda »proizlazi iz procesa samorazumijevanja i suodnosa, sučeljavanja osobnoga identiteta i vanjske realnosti ${ }^{42}{ }^{42}$ Prema Zlatar, a slično postavkama prikazane personalističke vizije čovjeka, »identitet se stvara u procesu razlikovanja, stalnoga uspostavljanja identiteta sebe u odnosu na druge, jastva u odnosu na druga jastva kao i na prepoznatu drugost $u$ vlastitome ja «, ${ }^{43}$ što je bitno različito od stoljetnog zapadnog kanona tjelesnosti kako ga je definirao Bahtin.

Prikazom različitih teorija tijela kroz povijesni razvoj dolazimo do spoznaja da suvremene teorije (filozofske, teološke, antropološke itd.) razbijaju antičku, srednjovjekovnu i kartezijansku dihotomiju duh/tijelo, koja se zapravo produbila $\mathrm{u}$ radikalnim feminističkim teorijama. Nova perspektiva poimanja tijela i tjelesnosti u humanističkim disciplinama očito računa s transcendentnom razinom.

Stoga ćemo, na temelju konstrukta tijela u tekstovima spisateljica hrvatske književnosti prve polovice 20. stoljeća, nadalje istražiti mogućnost da se u sklopu njihovih individualnih modernističkih poetika reprezentira takvo žensko tijelo, kakvo računa s izlaskom izvan zadanih okvira i dualističkih obrazaca. Prije istraživane reprezentacije majčinstva, budući da su usko povezane s reprezentacijama specifičnog ženskog tjelesnog iskustva, daju argument za nastavak istraživanja u tom smjeru. Naime, premda spisateljice prve polovice 20. stoljeća problematiziraju majčinstvo kao patrijarhalni društveni konstrukt i premda teže detabuizaciji javnoga govora o ranim majčinskim praksama (trudnoći, porodu, dojenju i postpartumu) ili neplodnosti, kršeći tako zazor zapadne kulture od nedovršenog i otvorenog, grotesknog tijela, za hrvatske je autorice prvih desetljeća 20. stoljeća majčinstvo uglavnom trenutak posvećenja ženstvenosti u kojem se spajaju fizičko i duhovno. ${ }^{44}$

\footnotetext{
${ }^{39}$ Poznata je personalistička teorija osobnosti Gordona Allporta prema kojoj je osobnost biološki determinirana od rođenja i oblikuje se u interakciji sa sredinom [usp. Saul MCLEOD, Theories of Personality, www.simplypsychology.org/personality-theories.html (30.01.2017)].

${ }^{40}$ Prema: Luka TOMAŠEVIĆ, Crkva se zauzima za cjelovito promaknuće čovjeka. Priopćenje sa znanstvenog skupa, Bogoslovska smotra, 3-4 (1995) 451-475, 459.

${ }^{41}$ Isto, 457.

${ }^{42}$ Andrea ZLATAR, Tekst, tijelo, trauma, Zagreb, Naklada Ljevak, 2004, 18.

${ }^{43}$ Isto, 21.

${ }^{44}$ Usp. radove Kornelija KUVAČ-LEVAČIĆ: »Trudnoća i porođaj - subverzivni motivi hrvatskog ženskog fantastičnog pisma«, Treća, 11 (2009) 1, 35-52; »Motivi ranih majčinskih praksa
} 
Prva značajna spisateljica kojoj je tjelesnost jedan od glavnih tema, ${ }^{45}$ posebice »majčinsko tijelo« koje je, zbog svoje specifične biološko-socijalne uvjetovanosti i premreženosti dodatnim značenjima što ga u nj upisuje kultura, mjesto prijepora i unutar feminističkog diskursa jest Zofka Kveder sa svojom zbirkom fragmenata Misterij žene (1900). Ispitat će se odnos Kvederove prema nametnutoj binarnoj opreci um/tijelo, odnosno duša/tijelo, kroz potrage ženskih likova za vlastitim identitetom i kroz »tipologiju muške i ženske ljubavi«, koja čini još jednu od tema njezine proze. Tjelesnošću kroz ta dva spomenuta tema usko su se bavile još dvije hrvatske spisateljice prve polovice 20. stoljeća, predstavnice tzv. »međuratne proze«: Mara Ivančan (ovdje će se analizirati njezin roman Čudnovata priča iz 1924.) i Mara Švel-Gamiršek (pripovijetke Snaša Terza i Snaša-Terzina posljednja ljubav iz njezine zbirke Portreti nepoznatih žena iz 1942.).

\section{Prema spiritualnosti tijela - fragmenti Zofke Kveder}

Pozornost Zofke Kveder, spisateljice koja je pisala na slovenskom, njemačkom, češkom i hrvatskom jeziku i koja otvara »moderno i modernističko žensko dvadeseto stoljeće «, ${ }^{46}$ u zbirci Misterij žene usmjerena je na »unutarnji svijet likova «, stavljajući naglasak na vezu žene i muškarca ${ }^{47}$ I Zlatar i Sablić-Tomić kod Kvederove su primijetile »iznimne diskurzivne kvalitete«, oznake modernosti u pisanju i izrazito feminističke teme. Zanimljivo je da, iako se prema nekim teoretičarkama koje su se bavile njezinim tekstovima, u središtu poetike ove autorice nalazi tijelo, ${ }^{48}$ autorica na prvoj stranici svoje knjige naglašava kako joj je namjera bila opisati »ženske duše i ženske sudbine «. ${ }^{49}$ Štoviše, prvi fragment $u$ zbirci donosi zapis o »utjelovljenim« ženskim dušama - duše su kroz autoričine

unutar konstrukcije književnih ideologema (J. E. Tomić, Melita, 1899. i Mara Švel-Gamiršek, Mati, 1942.)«, u: Sanjin KODRIĆ (ur.), Bosanskohercegovački slavistički kongres, Zbornik radova, knj. 2, Sarajevo, Slavistički komitet, 2012, 303-318; »Majčinstvo i identitet(i) modernih ženskih likova hrvatske književnosti s kraja 19. i početka 20. st.« - referat na Šestom hrvatskom slavističkom kongresu u Vukovaru i Vinkovcima 2014. godine, a bit će objavljen u Zborniku radova, knj. 2, 753-763 (rujan 2017); ili Milovan TATARIN, Što žene žele ili ponešto o feminizmu dvadesetih godina prošloga stoljeća, u: Nikola BATUŠIĆ i dr. (ur.), Dani hvarskoga kazališta, Hrvatska književnost, kazalište i avangarda dvadesetih godina 20. stoljeća, Književni okrug Split - Zagreb, HAZU, 2004, 107-135; i dr.

${ }^{45}$ Prema: Helena SABLIĆ-TOMIĆ, Gola u snu, Zagreb, Znanje, 2005, 71.

${ }^{46}$ Zlatar, Tekst, tijelo, trauma..., 56.

${ }^{47}$ Prema: Dunja DETONI-DUJMIĆ, Ljepša polovica književnosti, Zagreb, Matica hrvatska, 1998, 187, citat u: Sablić-Tomić, Gola u snu..., 65.

${ }^{48} \mathrm{Niz}$ je motiva koji se mogu povezati s iskustvom tjelesnosti u tekstu Kvederove, npr. motiv krvi, motiv pobačaja, motiv trudnoće, poroda, silovanja itd. (vidi više u: Kuvač-Levačić, Majčinstvo $i$ identitet(i) modernih ženskih likova hrvatske književnosti s kraja 19. i početka 20. st., 2014., bilj. 44 ovoga rada).

${ }^{49}$ Zofka KVEDER, Misterij žene, Zagreb, Matica hrvatska, 2004, 7. 
oksimoronske strukture poprimile karakteristike tjelesnog pa »gore« na »velikim žrtvenicima svjetova«, ${ }^{50}$ čime se vrlo vjerojatno prizivlje prošlost u kojoj je

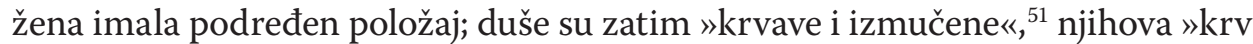
se slijeva preko oltara u beskonačnost «, ${ }^{52}$ pri porođajima duše su $» j e c a l e \ll .53$

Očito je da se kroz ovu gotovo ekspresionističku metaforizaciju provlači ideja o izjednačavanju kategorije duša/tijelo, o svojevrsnoj »tjelesnosti« duše (»Krvi duša. Ženskih.«), ${ }^{54}$ odnosno spiritualizaciji tijela - pjesničke slike »krvavih duša« koje se žrtvuju na oltaru asociraju na žrtvovanje tijela, i to kao kristološki motiv. U trinaestom fragmentu, u kojem se ponavljaju slike žena koje se žrtvuju kroz porođajne muke, ponavlja se i vizija duše koja opet poprima oznake tijela: »I tijela su se otkidala iz tijela, duše se rezale, izvijale, lomile iz duša! « 55

Zanimljiva je činjenica da Kvederova o duši i tijelu piše u množini, odnosno uvijek je slučaj duša (mn.) koje se spajaju jedna u drugu, koje se zajedno lome i zajedno proživljavaju. U spomenutom trinaestom fragmentu opisuje se kao vizija jedan porođaj - »Jednom, usred noći čuo se u rodilištu krik«; »Rodio se čovjek! ${ }^{56}$ - koji zatim aktivira cijeli niz dotadašnjih porođaja koje su »žene svijeta ${ }^{57}$ morale podnijeti. U tom jednom porođaju u sadašnjosti vizijom spisateljice ujedinjeni su svi porođaji. U množinskom se obliku donose i prethodno citirane slike »utjelovljenih« duša iz prvog fragmenta. Ako bismo napravili paralelu s personalističkom teorijom osobnosti, takve slike mogle bi odgovarati socijalnoj dimenziji tijela, spomenutoj u prethodnom poglavlju, koju dokazuje činjenica da čovjek putem »tijela stupa u odnose s drugima i tako ostvaruje sebe ostvarujući zajedništvo « ${ }^{58}$ Ostvarivanje sebe, odnosno kreiranje vlastitog identiteta stvara se, dakle, u odnosu »jastva« naspram »drugih jastava«, kao i na $»$ prepoznatu drugost $u$ vlastitome ja«. ${ }^{59}$ Kvederova je $u$ potrazi ne samo za vlastitim identitetom već i za, u vlastitom identitetu projiciranim, drugim »ženskim « identitetima koje je bilo teško utvrditi i pronaći u ovdje promatranom razdoblju hrvatske književnosti izvan uloge »moderne« žene kao majke i ljubavnice. ${ }^{60}$

Potraga za tjelesnim oznakama duše, odnosno potraga za spiritualnošću tijela, zapravo je traganje za »cjelovitim gledanjem na čovjeka ${ }^{61}{ }^{61}$ koje se sasto-

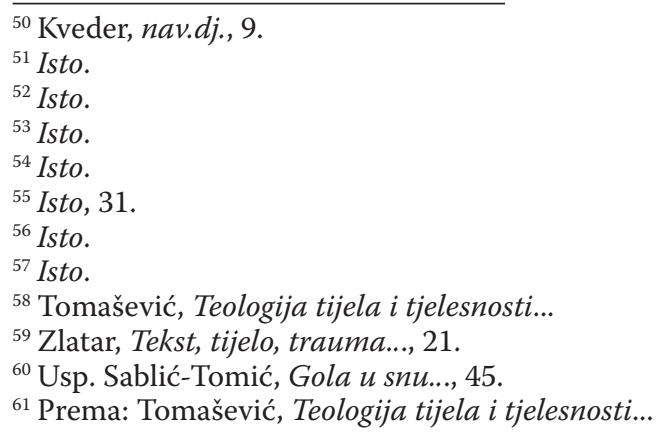


ji istovremeno i od duhovnog i tjelesnog, razuma i strasti, pameti i osjećaja, izvanjskog i unutarnjeg itd., kako smo čitali i kod E. Grosz. U sklopu takve vizije tijela, utemeljene na personalističkoj teoriji čovjekove osobnosti koja izjednačava kategorije duhovnog i tjelesnog (uz naglašenu važnost kategorije socijalnog), a kojemu teži Kvederova, potrebno je detaljnije proširiti razumijevanje binarne opreke vlastito/tuđe u spomenutom nizu. Već je nagoviješteno da se tijela u svojoj cjelovitosti ostvaruju tek u zajedništvu s drugim tijelima. I Nancyeva filozofija ontološkog tijela smisao tijela vidi u zajedništvu s drugim tijelima te će u sljedećem poglavlju istraživanje tekstova ostalih najavljenih spisateljica ići u tom smjeru, sa sviješću da ga prati predrasuda, o kojoj govori S. Wendell, prema kojoj su kreatori različitih feminističkih teorija žensko tijelo gledali kao odvojeno, ne bi li ga otuđena povratili ženi, posebno naglašavajući njegove razlike i udaljenosti od drugog tijela, dakako »muškog «. ${ }^{62}$

\section{Tijela u potrazi za drugim tijelima - tzv. »tijela zajednice « ${ }^{63}$}

Osim što u svojim fragmentima tematizira uglavnom tijelo, Kvederova tematizira i »zrcalni odraz žene kroz muškarca jer sama je žena bezsudbinska, a tek kroz Njega može postati cjelinom «. ${ }^{64}$ Ovakvu tvrdnju Sablić-Tomić pojašnjava naglašavajući da se je spisateljica istovremeno bavila podređenim položajem žene u takvom patrijarhalnom odnosu..$^{65}$ Doista, kad opisuje ljubavni odnos muškarca i žene, Kvederova jasno ističe razlike u njihovu pristupanju tjelesnosti te na mnogo mjesta naglašava patrijarhalnu obojenost muškarčeva odnosa prema ženi, težnju za ostvarivanjem moći. Muškarac je onaj koji je pohotan, koji ne može obuzdati vlastite požudne nagone, koji je potreban ženina tijela: »Žudio je za bijesnim, punim vrućim udovima, za bakanalima pohote. ${ }^{66}$ Iz možda manje nagonskih pobuda (bar to tako kaže spisateljica), i naravno u podređenom položaju, i žena je prikazana kao ona koja čezne za spajanjem, za drugim, za dodirom: »Njene blijede, bolesne ruke plakale su za njim. ${ }^{67}$ (ista slika ponavlja se dva puta u ovom fragmentu).

No, ako već prije istaknutu tvrdnju Z. Kveder nakratko promotrimo izvan okvira antipatrijarhalnog angažmana, možemo vidjeti da autorica zapravo

\footnotetext{
${ }^{62}$ Wendell, nav. dj., 196.

${ }^{63}$ Sintagma preuzeta iz istoimenog članka Tijela zajednice Bernarda Harbaša, u kojem se raspravlja o filozofiji tijela Jean-Luca Nancyja. Harbaš iznosi Nancyjevu filozofiju o singularnoj pluralnosti, odnosno o tijelima kao principu zajednice. Tijela dobivaju svoj smisao tek u izloženosti drugim tijelima, u dodiru ili kontaktu, ona su upućena jedna na druga. Smisao se ne traži u »okupljanju vlastitog identiteta«, već u zajedničkom »su-bivstvovanju« različitih singulariteta (usp. Harbaš, nav. dj., 440).

${ }^{64}$ Sablić-Tomić, Gola u snu..., 65.

${ }^{65}$ Usp. isto, 66.

${ }^{66}$ Kveder, nav. dj., 20.

${ }^{67}$ Isto.
} 
otvara temu »egzistencije«, našeg identiteta »određena izloženošću tijela drugim tijelima«, kako je naveo Harbaš. ${ }^{68}$ Francuski profesor psihologije Fabrice Hadjadj dodirivanje tijela drugoga vidi kao način uspostave odnosa s vlastitim tijelom: »No, dakle, što se događa kada dodirnem? Tada sam i sam dodirnut «, ${ }^{69}$ odnosno kao afirmaciju vlastitoga tijela. ${ }^{70} \mathrm{Na}$ drugom mjestu, isprepletanje muškog i ženskog tijela, ostvarivanje jednog (Ja) pod uvjetom dodira s drugim (Ti), ovog puta u muško-ženskoj ravnopravnosti, Kvederova donosi u metaforičnoj slici tjelesnog odnosa u desetom fragmentu:

»Tvoja ljubav je lila na mene, tvoje oči rastapale su moju hladnoću i potekli su svi studenci moga bića. Vreli, čežnjivi osjećaji preplavili su moju dušu, moja je krv zakričala: Ti! Ti! Ti! Zakričala je i svi živci zatreptali su i želje su se kao ognjena lava razlile po čistoj golotinji mojih osjećaja. I iz očiju mi je zasjala čežnja i sva $J a$ gorjela sam od želja.«11

U navedenom citatu je također moguće uočiti metaforičku identifikaciju tjelesnih i duhovnih stvarnosti: golotinja osjećaja, želje koje se razlijevaju poput lave; te na drugom mjestu u fragmentu »strah krvi šutljive duše«, poziv muškarcu da uđe u bogatstvo njezine tjelesnosti: "povukla bih Te u sebe, u duboke, vrele vrtloge svoga bogatstva $\aleph^{72}$ te pridodavanje duhovnih osobina tjelesnom $u$ motivima poput: krvi koja je zakričala, čežnje u očima, tijela koje gori od želja, nezasitnih ruku itd.

Spisateljice Mara Ivančan i Mara Švel-Gamiršek također su tematiku tjelesnosti obrađivale kroz prikaz muško-ženskog odnosa. U romanu Mare Ivančan Čudnovata priča (1924) Emilija Kovač iščitava elemente angažiranog teksta, gdje se kao tema ističe »socijalni i ideološki problem - položaj žene u društvu« ${ }^{73} \mathrm{U}$ središtu priče je Marija Katićeva, poštarska službenica koja ostaje trudna s čovjekom što joj nije zakoniti muž, odbija njegovu ponudu za brak i odlučuje sama roditi i podići dijete. Otežani položaj žene zbog takve odluke očitovat će se kroz različite načine u sadržaju romana: počevši od društva koje osuđuje takav čin, u vidu činovnika iz ureda, pa do vlastite sestre Ane kojoj nije jasan Marijin izbor. ${ }^{74}$ Tekst Mare Ivančan je usmjeren prema borbi protiv patrijarhalnog sustava kakav se snebivao nad ženama koje su ostajale trudne izvan braka i koje se potom nisu htjele udati. Međutim, ostaju otvorena pitanja: kakav je bio onaj uski intimni muško-ženski odnos u romanu, kakve su bile posljedice

\footnotetext{
${ }^{68}$ Harbaš, nav. dj., 436.

${ }^{69}$ Fabrice HADJADJ, Dubina spolova, Zagreb, Kršćanska sadašnjost, 2011, 97.

${ }^{70}$ Teoriju dodira na ovom tragu donosi i Andrea Zlatar u svojoj knjizi Rječnik tijela, gdje posebno objašnjava nemogućnost odjeljivanja dvaju tijela koja se dodirom spajaju: »Ne mogu reći tko je u poljupcu, kao što više ne znam tko koga drži za ruku, ja tebe ili ti mene... Osjećamo sve: potpunost, stopljenost...« (Andrea ZLATAR, Rječnik tijela, Zagreb, Ljevak, 2010, 23).

${ }^{71}$ Kveder, nav. dj., 25.

${ }^{72}$ Isto, 26.

${ }^{73}$ Emilija KOVAČ, Modernizam u djelu Mare Ivančan (2002), www.matica.hr/kolo/288/ Modernizam\%20u\%20djelu\%20Mare\%20Ivan\%C4\%8Dan (25.01.2017).

${ }^{74}$ Usp. isto.
} 
Marijine hrabre i neizbježne angažirane odluke da se odijeli od muškarca i postane samostalnom, kakav je doživljaj tjelesnosti glavne protagonistkinje? Žudi li i dalje njezino tijelo za odnosom s drugim tijelom, je li njeno tijelo - tijelo zajednice ili je sasvim odijeljeno, dovoljno samo sebi?

Potrebno se zaustaviti na početnim stranicama romana gdje je opisan odnos Marije i Nikole: »Njihov je odnos bio jedna čisto seksualna iskrena sklonost. $\ll^{75}$ Ipak, nakon prekinuta odnosa Marija osjeća prazninu:

»(...) pa jer su je prekinuli baš onda, kad je bila na kulminaciji, osjećala je Marija jednu tešku prazninu iza Križanova odlaska, no ta praznina trajala je kratko. Bilo joj je kao čovjeku kome operacijom oduzmu dio njegova tijela, pa kad se probudi iz narkoze, osjeća veliku i bolnu prazninu, osjeća olakšicu koja boli.« . $^{76}$

Filozof Jean-Luc Nancy u radu O singularnom pluralnom bitku objašnjava da je »svatko pored-sebe utoliko ukoliko je i zato jer je pored-drugih. 'Mi' smo prvo jedni s drugima (...) kao bitak jedni s drugima «. ${ }^{77}$ Tijela tek u svom kontaktu s drugim tijelima proizvode značenja, stvaraju zajedničku egzistenciju, na kraju proizvode i samu stvarnost jer kroz »dodir, kroz ispunjavanje prostora, svijet se stvara «. ${ }^{78} \mathrm{Kad}$ se Marija svojom vlastitom odlukom tjelesno odvaja od Križanova tijela, ona prema takvom ontološkom, singularno pluralnom konceptu tjelesnosti, negira vlastitu stvarnost uspostavljenu tim odnosom, što se na osjećajnoj bazi očituje kao »velika bol i praznina«. Prema Nancyu, tijela se u dodiru »oprostoravaju«, postaju smisao:

»'Moj' spol nije nešto potpuno; on je poseban, bez određenog modela, sadržajan kontakt prostora - koliko mog tijela, toliko i drugih tijela - moje tijelo postaje drugo tijelo dodirujući sebe u tom prostoru, odnosno bivajući dodirnuto. Ono postaje isto tijelo s drugim, i potpunije i razdvojenije nego ikad - mjesto dodira (davanja), ali i širenja.« ${ }^{79}$

Je li ukidanje odnosa prema drugim tijelima negiranje njegovih osnovnih značajki: stvaralaštva, egzistencije-postojanja u svijetu? U Čudnovatoj priči takve se ideje mogu sadržajno utvrditi: Marija je u tjelesnom odnosu s Križanom ostala trudna, udaljila se tjelesno od njega, ali što je udaljenija, to je sve više izvan stvarnosti i ulazi u prostor snova i halucinacija - sanja da je rodila i da joj dijete želi privući i na kraju vjerojatno i oteti, nekakav čudni starac koji dijete i nju u stopu prati i dovodi do ludila. Marija sad obitava u bestjelesnom prostoru, sasvim je bez kontakta s drugim stvarnim tijelima, nesvjesna same

\footnotetext{
${ }^{75}$ Mara IVANČAN, Čudnovata priča, Zagreb, Naklada Mlinarec i Pavić, 2004, 10.

${ }^{76}$ Isto, 10.

${ }^{77}$ Jean-Luc NANCY, Dva ogleda, Zagreb, Naklada Jesenski i Turk, 2004, 133.

${ }^{78}$ Bernard HARBAŠ, Tijela zajednice, Filozofska istraživanja, 28 (2008) 110, 438.

${ }^{79}$ »'My' sex isn't one thing throughout; it's a discrete, random, eventful contact of the zones of 'my' body, as much as of others - my body becoming other, by touching itself there, by being touched there, becoming thereby the same, more absolute, more separated then ever, more identified as a taking place of touching (of extension) (Nancy, nav. dj., 37) (prev. A. Vulelija).
} 
sebe: »Snivala? - pitala je Marija ${ }^{80}{ }^{80}$ Zanimljivo je utvrditi, a to ide u prilog tezi o tijelu koje svoj smisao dobiva u kontaktu i supostojanju s drugim tijelima, da se starac kojeg Marija sanja cijelo vrijeme tjelesno približava njoj i sinu (jer $\mathrm{u}$ tom tjelesnom smislu Marija je trenutno bez prostora, bez kontakta s drugim tijelom od kojeg se svojim izborom odijelila, ona je u prostoru praznine i njezina onirička fantazmagorija može se interpretirati kao simbolizacija te izdvojenosti):

»Postrance na krevetu sjedi zagonetni luđak s pačjim profilom i ljubičastom maramom i drži za ruku moje dijete... O kad bih samo mogla da se maknem! Ne mogu! Noge su mi teške... Onaj debeli još uvijek naslanja svoje tijelo na me... « ${ }^{81}$

Marija je, s druge strane, neprestano izložena tuđim tijelima koja žele prisvojiti prostorno pravo na nju:

»'Ta maknite se vi, gospa, šta ste se tako prislonili na me' - opomene me neki debeli muškarac... 'A šta se gurate opet, vi, tu' - okrene se žena što je preda mnom i gurne me laktom $\mathrm{u}$ želudac. $\ll^{82}$

S vremenom Marijino tijelo (u priči koju sanja) propada, osipa se: »Omršavila sam od bijede, osijedila od brige i poružnila od posla i lošeg odijevanja. « ${ }^{83} \mathrm{U}$ isto vrijeme starac je sve više tjelesno prisutan uz dječaka (kojeg također sanja da je rodila), posebice onda kada mu treba nekakav oslonac, pomoć: »No odan je samo onoj zagonetnoj pojavi, koja se fatalno ispoljava svagdje, gdje moj sin treba oslona, pomoći, svagdje gdje dolazi u opasnost. ${ }^{84}{ }^{84}$ starac nestaje samo onda kad (sanjani) dječak pokaže odlike svoje tjelesne, muške snage: »Sretna sam jer je moj sin pun muškaračke odvažnosti i silovitosti... On je otišao, a moj sin je opet samo moj. $\ll^{85}$

Smještajući egzistenciju protagonistice u neopipljive prostore sna, spisateljica možda i nesvjesno oduzima »stvorenost « ${ }^{86}$ njezina tijela, »ograničenost materijalnog u tijelu koje je temelj socijalnog života jer čovjek može živjeti samo u zajednici razmjene $\ll{ }^{87}$ Ovakvi postupci također su usmjereni kreatorima patrijarhalne moći, međutim ovdje se otvara mogućnost iščitavanja vizije

\footnotetext{
${ }^{80}$ Ivančan, nav. dj., 64.

${ }^{81}$ Isto, 47.

${ }^{82}$ Isto, 45.

${ }^{83}$ Isto, 57.

${ }^{84}$ Isto.

${ }^{85}$ Isto, 52.

${ }^{86}$ Pojam »stvorenost tijela« (creaturitas) Tomašević preuzima iz naučavanja o teologiji tijela pape Ivana Pavla II. (Ivan PAVAO II., Muško i žensko stvori ih. Kateheze o ljudskoj ljubavi, sv. I, Split, Verbum, 2012) objašnjavajući ga kao »podrijetlo« tijela - »čovjek je stvoren« kao »nepostojan, lomljiv i krhak«, drugim riječima, tjelesan. Tjelesnost se u okviru teologije tijela shvaća kao »dar«, kao mogućnost da čovjek »upotrebljava čitavo tijelo«, takvo kakvo jest, sa svim nesavršenostima, odnosno da razvija sve njegove »implicitne mogućnosti«, npr. služenje drugima (usp. Tomašević, Teologija tijela $i$ tjelesnosti...).

${ }^{87}$ Tomašević, Teologija tijela i tjelesnosti...
} 
o tijelu koje je uvijek u potrazi za onim drugim s kojim bi se »oprostorilo « ${ }^{88} \mathrm{~s}$ kojim bi izgradilo vlastitu egzistenciju i na taj se način izdiglo na ontološku razinu, iznad isključivo materijalističkog shvaćanja tijela. Tijelo Marije Katićeve, izolirano od drugog tijela koje bi u ontološkom smislu nadopunjavalo njezino, propada, gubi svoju prostornost te protagonistica na kraju djela završava tragično. Ono dakle ne gubi svoju prostornost zato što se odijelilo od »muškog« pa stoga i važnijeg tijela, već zato što je »iznevjerilo« vlastitu dimenziju koja ga upućuje na zajedništvo s drugim tijelima, oprostoravanje.

Odnos ženskog prema muškom tijelu prikazan je i u nekoliko pripovijedaka Mare Švel-Gamiršek u zbirci Portreti nepoznatih žena (1942). Zbirka donosi niz ženskih sudbina koje »svojim životom i svjetogledom vrlo često nisu zadovoljavale kanon življenja, bilo da su izgledom odvlačile pozornost, ili da su pogledom na život remetile moralne konvencije življenja«. ${ }^{89}$ Snažne reprezentacije ženskog tijela uočavamo u pripovijetkama Snaša Terza i Snaša-Terzina posljednja ljubav. Ostvaruju se u opoziciji dviju protagonistica, majke i kćeri, koje različito žive vlastitu seksualnost. Tijelo promiskuitetne Terze prikazuje se kao seksualno privlačno:

»Snažna i mlada u najljepšim godinama, jedra i punačka sličila je zdravoj rumenoj jabuci. Samo da zagrizeš u nju. Tek ne znaš kuda. U rupicu kod lakata, koja izazovno viri pod zadignutim rukavom oplećka; u obraz što je breskvi sličan, ili u usne naprćene i rumene kao jagode. ${ }^{90}$

Takvo tijelo postaje temelj ostvarivanja različitih veza s muškarcima, koje Terza uspostavlja uglavnom vođena ekstrinzičnim motivima kao što su ugled i bogatstvo ili sama privlačnost mladih muških tijela. Njezini odnosi s drugima prikazani su kroz slike tjelesnih kontakata; odnos sa slugom, mladićem Lukom: »Uhvatio ju je za ruku, povukao k sebi... obavio njezin struk. Osjetio je kako štrepi. - Luka! - kriknula je i osjetila uz sebe, kako mu srce snažno udara. Tada ju je zajedno sa sobom prebacio preko nedovršenog drvetara. $\ll ;^{91}$ odnos sa starim Matom: »Zašto da se predomišljavaš? - kazao je on i drhtavom rukom je obavio oko struka, a ona je osjetila kako je jeza hvata od gađenja nad staračkom blizinom. ${ }^{92} \mathrm{U}$ sljedećoj pripovijetci Snaša-Terzina posljednja ljubav Terzino

\footnotetext{
${ }^{88}$ "Dodir, tj. kontakt, ostvaruje se u prostoru. Pitanje prostora, odnosno oprostoravanja (espacement), temeljno je za Nancyevu filozofiju tjelesnosti. Dodir, kontakt, uvijek se ostvaruje između, među tijelima, u prostoru. Prostor je uvijek nešto što se dijeli. Drugim riječima, dijeljenje zajedničkog prostora, dodirivanje - jest oprostoravanje. Samo u oprostoravanju tijela konstituira se smisao. Nije riječ o pukom pozajedničavanju, ili o nekom ustrajnom stapanju, već o dodirivanju, ali i razdvajanju. Tijela su uvijek već singularno su-bivstvovanje. Ona jesu su(djelovanje) bez stapanja, jer se uvijek već u svojoj oprostorenosti i razmiču« (Harbaš, nav. dj., 436).

${ }^{89}$ Helena SABLIĆ-TOMIĆ, Počeci slavonskog ženskog pisma, u: Nikola BATUŠIĆ (ur.), Dani hvarskog kazališta, knj. 34, br. 1, Književni okrug Split - Zagreb, HAZU, 2008, 78-88, 85.

${ }^{90}$ Mara ŠVEL-GAMIRŠEK, Portreti nepoznatih žena, Vinkovci, Slavonica, 1992, 26.

${ }^{91}$ Isto, 27.

${ }^{92}$ Isto, 31.
} 
senzualno tijelo i dalje je polazište uspostave odnosa sa suprotnim spolom: »Punačka je bila, no čvrsta i svježa. « ${ }^{93}$ Takva dočekuje mladog inženjera Miru i uspostavlja s njim tjelesni kontakt: »Jedne je večeri, ispričavajući se, da je u sobi toplo, dočekala inžinira Miru gologlava, bez kukme. (...) U njegovim je očima sijevnulo, a kad je ona ustala, zagrlio ju je naglo i pritisnuo svoja usta na njezina. $\ll^{94}$

$\mathrm{U}$ isto vrijeme u objema pripovijetkama se pojavljuje lik Terzine plahe i dobrodušne kćeri Marice u čijem opisu tijela je spisateljica znatno suzdržanija: $»(. .$.$) i bilo joj je drago što je noć i što joj on ne može u oči pogledati .^{95}$ Opisujući njezin tjelesni izgled, M. Švel-Gamiršek je više usmjerena na osobnost same protagonistice nego na atribute tijela, što vidimo u klišeizaciji opisa: »Fino, duguljasto lice, zarumenjeno od brzog hoda, bilo je k njemu okrenuto, i dva krupna plava oka ispod dugih tamnih, zavrnutih trepavica, gledala su ga začuđeno. « ${ }^{96}$ Kontrastni prikazi poljubaca prate kontrast karaktera glavnih ženskih likova. Tako je poljubac sa snašom Terzom prikazan kao erotska predigra, ${ }^{97}$ a onaj s Maricom kao iskaz iskrene ljubavi. ${ }^{98}$

Opise poljubaca nagovijestili su već i opisi usana dviju žena: Terzin je obraz breskvi sličan, a usne naprćene i rumene kao jagode, dok se Marica svojim ružičastim usnama, koje skrivaju zdrave, bijele zube, radosno smije ${ }^{99}$ Crvena boja usana, kao boja strasti, krajnosti, razornih osjećaja i nagonskih poriva, ${ }^{100}$ nosi u sebi skriveno simboličko značenje koje dodatno učvršćuje likove na njihovim oprečnim moralnim pozicijama te nagoviješta tijek radnje. Crvenoj u suprotnost dolazi boja ruže, boja Maričinih usana, koja simbolizira čašu života, dušu, srce $i$ ljubav ${ }^{101}$ I religijski motivi se pojavljuju kao ključni u razdvajanju dvaju suprotstavljenih ženskih likova, njihovih karaktera i odnosa prema tijelu: Marica se često zadubljuje u požutjelo Sveto pismo, ${ }^{102}$ a Terza prekida s moralnim ponašanjem otprilike u vrijeme kad umire stara strina, koju su našli jedno jutro mrtvu u krevetu s krunicom u ruci. ${ }^{103}$

Iako Mara Švel-Gamiršek uvelike zadržava poziciju tradicionalnog dualizma (naglašena tjelesnost, erotičnost, crveno - pozicija grijeha i požude kod Terze,

\footnotetext{
${ }^{93}$ Isto, 48.

${ }^{94}$ Isto, 51.

${ }^{95}$ Isto, 77.

${ }^{96}$ Isto, 68

${ }^{97} »$ Približio joj se. Ona je podigla glavu i pogledala u njega, on je u tom pogledu pročitao želju. U njegovim je očima sijevnulo, a kad je ona ustala, zagrlio ju je naglo i pritisnuo svoja usta na njezina $($ isto, 51$)$.

98 »Ona ga je shvatila i s puno povjerenja naslonila svoju glavu na njegovo rame. Tad je on pobožno taknuo njezinih zatvorenih vjeđa svojim usnama« (isto, 78 ).

${ }^{99}$ Usp. isto, 26, 42.

${ }^{100}$ Colin DIDIER, Rječnik simbola, mitova i legendi, Zagreb, Naklada Ljevak, 2004, 90.

${ }^{101}$ Jesan CHEVALIER, Alain GHEERBRANDT, Rječnik simbola, Zagreb, Naklada Jesenski i Turk, 2007, 628.

102 Švel-Gamiršek, nav. dj., 71.

${ }^{103}$ Isto, 28.
} 
nasuprot tek naznačenoj tjelesnosti, nježnost, ružičasto - pozicija etičnosti i duhovnosti), kod nje nalazimo i dva različita koncepta seksualnosti; kao isključivo tjelesne manifestacije ili, kako je već govoreno u poglavlju o Kvederovoj, personalistički, u isprepletanju različitih čovjekovih razina. ${ }^{104}$ Između Mire i Terze događa se tjelesna ljubav koje je oznaka »težnja« muškarca i žene »da se služe fizičkim danostima «105 u međusobnom kontaktu, dok je seksualnost Marice i Mire ostvarena kao ona koja obuhvaća cijelu osobu, bez postavljanja granica između duha i tijela. Terza kao lik, doduše, ima slobodu i donosi vlastite odluke $u$ vezi sa svojim tijelom, ali to je na koncu ne ispunjava te završava kao "promašena« osobnost (što spisateljica, koja je neizbježno angažirana ovim tekstom, svjesno izabire kao scenarij za Terzu) i na koncu ne ostvaruje u potpunosti svoje tijelo, u ontološkom smislu. I ovdje, kao i kod M. Ivančan, odjeljivanjem od drugih tijela, Terzino gubi vlastiti »prostor», vlastiti »bitak«, ${ }^{106}$ na koncu i identitet: »Znala je da je njezin dalji put pust, da je život promašen i da ne može očekivati ništa što bi radošću ispunilo njezinu dušu... «107

\section{Zaključak}

Spisateljice koje su se našle u središtu književne produkcije prve polovice 20. stoljeća u Hrvatskoj imale su zahtjevan zadatak - opravdati vlastitu literarnu sposobnost, želju za pisanjem i sudjelovanjem u književnom životu. Onodobna kritika njihovih djela temeljila se na isticanju razlika koje se mogu rezimirati kroz opozicije: um, duša/tijelo, razumno/strastveno, izvanjsko/unutarnje, transcendentno/imanentno, pri čemu je ženskom pripala pozicija drugoga. Teorije koje su još od antičkih filozofa stvarale temelj ovakvih konstrukta - Aristotelovi i Platonovi stavovi, Descartesov dualizam duh/tijelo, kršćanski pogledi na tjelesnost u srednjovjekovlju, nekoliko stoljeća percipiranja tijela kao zatvorenog i odvojenog, za razliku od otvorenog i nedovršenog, grotesknog tijela u bahtinovskom smislu, prema kojemu se osjeća zazor itd. - sve to dovelo je do reakcija u feminističkim teorijama druge polovice 20. stoljeća.

I one su međutim, prema kritici S. Wendell, na svoj način negirale žensko tijelo, pokušavajući ga izjednačiti s muškim tijelom i potkopavajući biološke razlike koje postoje između spolova. Ideju transcendentnosti tijela, koja bi uzela u obzir duhovnu i fizičku dimenziju tijela, dominantno su zanemarile i time ostale na pozicijama starog dualizma. Transcendentnom dimenzijom tjelesnosti bavile su se filozofska i kršćanska antropologija i suvremena filozofija i teologija tijela, neke od njih izrazito povezane s personalističkim teori-

\footnotetext{
${ }^{104}$ Usp. Petar ŠOLIĆ, Moralni aspekti ljudske seksualnosti, Split, Crkva u svijetu, 2002, 12-13.

${ }^{105}$ Isto, 15.

${ }^{106}$ Harbaš, nav. dj., 437.

107 Švel-Gamiršek, nav. dj., 83.
} 
jama osobnosti koje čovjeka cjelovito promatraju kao neodjeljivost duhovnog i tjelesnog. U radu smo se služili ključnim postavkama Nancyjeve filozofije o »tijelima zajednice« unutar koje su tijela ontološka, promatrana u singularnom pluralitetu, i kojih se bitak i smisao ostvaruju u kontaktu s drugim tijelima, kroz ideju oprostoravanja tijela.

Primijenili smo ih na tekstove spisateljica Zofke Kveder, Mare Ivančan i Mare Švel-Gamiršek kod kojih je već otprije u literaturi bila utvrđena izrazita usmjerenost na reprezentacije ženskog tijela i specifično iskustvo tjelesnosti. Ovim istraživanjem pokazujemo da je kod spomenutih autorica moguće ženska tijela interpretirati kao ontološka u kojima je jasno narušen dualistički koncept, a što je vidljivo na razini literarnih postupaka autorica. Kvederova u zbirci fragmentarne lirske proze Misterij žene konstruira »otjelovljenu« žensku dušu kroz oksimoronsko poistovjećivanje tjelesnih i duševnih osobina, bilo da ih ostvaruje kroz tematiku specifičnog iskustva ženske tjelesnosti motivom porođaja ili tematikom seksualnog odnosa muškaraca i žena. Ona stvara koncept ontološkog tijela ili tijela zajednice, »oprostorenog « kroz dodire drugih tijela (bila to muška s kojima se tjelesno spajaju ili druga ženska, s kojima ih spajaju ista proživljena tjelesna iskustva - motiv porođaja, nasilja, seksualnog odnosa i sl.) ili stilogenim poigravanjem imenicama u jednini i množini (singularna pluralnost), gdje je identitet jedne žene poistovjećen kroz tjelesno iskustvo $\mathrm{s}$ identitetima sviju ostalih. Dodiri i zajedništvo ispisuju prema Nancyju bitak, smisao i postojanje tijela. Kvederova upravo posredstvom takvog tijela zajednice konstruira ženski identitet u svom, nesumnjivo antipatrijarhalno angažiranom modelu.

Spisateljica Mara Ivančan koncept tjelesnosti, makar u okviru nešto drukčijih individualnih poetičkih odrednica, također vezuje uz ideju singularne pluralnosti, odnosno tijela zajednice. Borba protagonistkinje je neminovno usmjerena protiv patrijarhata u kojoj samoizolacija ženskog tijela zapravo postaje pozicija otpora. Lik M. Ivančan »osuđen« je na tjelesnu izolaciju po vlastitom izboru, čime autorica, s jedne strane, literarno uprisutnjuje ideju da žena ima pravo odlučiti što želi učiniti sa svojim tijelom, no, s druge strane, u toj izolaciji ne vidi krajnje rješenje, što realizira konstantnim, često konfliktnim susretima protagonistice Marije s tjelesnošću drugih (u fiktivnoj stvarnosti i u fantazmagoriji protagonistkinje), kao i u njezinom nesretnom okončanju. Razvidno je da izolacija tijela odvaja glavnu protagonistkinju romana Čudnovata priča od bitka, stvarnosti i egzistencije.

Treća spisateljica Mara Švel-Gamiršek nudi dva koncepta tjelesnog. U liku Snaše-Terze naglašeno je i podrobno razrađeno materijalno tjelesno, zatvoreno i izolirano u svojoj erotičnosti, kojim ne uspijeva ostvariti »tijelo zajednice« i zbog kojega osobnost protagonistkinje ulazi u poziciju objekta, stoga i nesretno skončava. S druge strane je lik Marice, čije tijelo promovira autoričine duhovne, primarno kršćanske vrijednosti. Tako su tijela Snaše-Terze i Marice 
konstruirana kao ostvaraji dvaju suprotnih idejnih koncepata, što je naglašeno u kontrastnim opisima istih tjelesnih manifestacija kod obiju protagonistkinja: poljupca, izgleda djevojačkog lica, reakcija na dodir muškarca i sl., iako uz primjetnu klišeizaciju. Mara Švel-Gamiršek ostvaruje ontološko tijelo kroz takvo definiranje oprečnih dodira kao izvornog kontakta kroz koji se konstruira smisao, ${ }^{108}$ ne razvijajući svoj angažman isključivo na dualističkom poimanju (makar je ono još uvijek prisutno više negoli u drugih obrađenih spisateljica).

U obrađenim se književnim tekstovima potvrđuje mogućnost interpretacije konstrukta ženskog tijela kroz Nancyjevu ideju o tijelu koje postaje smisao, bitak tek u susretu s drugim tijelima, u kontaktima. ${ }^{109}$ Time možemo zaključiti da su se spisateljice više ili manje odmakle od ustaljene predodžbe tijela - odijeljena od uma i duše, podložna isključivo zakonima materije, pa onda tako i vrjednovana. Njihov se koncept tjelesnosti, dakle, ne može tumačiti shvaćanjima koja negiraju žensko tijelo uz isticanje isključivo duhovne dimenzije ženskog identiteta radi dosezanja ravnopravnosti s muškarcem. Ideja da tijelo dobiva svoj značaj, bitak tek u dodiru s drugim tijelima može također naići na osude kao patrijarhalni pogled (ukoliko se shvati da su ženska tijela bez muških nevrijedna, nepotpuna). Međutim, ona ide u sasvim drugom smjeru, prema konceptu ontološkog tijela, i zapravo je usmjerena k razbijanju dihotomije duh/ tijelo, vlastito/tuđe. Takav se koncept tjelesnosti nudi kao konstitutivni element u izgradnji poetika hrvatskih spisateljica prve polovice 20. stoljeća koje su se njime uklopile u nove, modernističke tokove tadašnje hrvatske književnosti.

\footnotetext{
${ }_{108}$ Prema Harbaš, nav. dj., 435.
}

${ }^{109}$ Nancy, nav. dj., 2004, 133. 


\section{Kornelija Kuvač-Levačić* - Ana Vulelija** \\ The concept of ontological body in first half of the 20th century literature by female Croatian writers}

\section{Summary}

Whole history of Western thought has the experience of corporeal, in association with woman and femininity, related with images of subordination or supernatural sublimity, based on dualistic concept of body/soul, which however had no real connection with experience of being inside a woman's body. So, we aren't amazed by the fact of different feminist movements in second half of the 1900 s concentrating on the question of woman's corporeal experience in specific social communities, but without attempts to prove the possibility of physical transcendentalism, thereby turning towards the paradox of deepening dualism. By the first half of the 20th century female Croatian writers have already recognized the subject of body and corporeality as a potential in building their own engaged literature. The issues that this work is primarily addressing to are framed by the display of the circumstances in which Croatian female writers created, in correlation with opposing concepts of mind/body, male/female, in which the presentation of a man correlates with the mind and a woman with the body by Elisabeth Grosz's corporeal feminism theory (Grosz 1994), and they refer to representations of the body and corporeality in the literary works of those female authors who have placed this subject in the centre of their literary interest. We'll also show that these female authors (Zofka Kveder, Mara Ivančan, Mara Švel-Gamiršek) are trying to reinterpret the female body in such way that it elevates above mentioned, culturally accepted binary oppositions. We will question the possibility of reading the transcendent, ontological, i.e., philosophical body in their texts. Philosophical body is one of the most important problems of contemporary philosophy, according to philosopher Jean-Luc Nancy's theory, which dealt specifically with breaking the binary opposition spirit/body and gave new meaning to the body. The corpus of texts processed in this work will consist of: collection of fragments "The Mystery of a Woman" by Croatian-Slovenian-Czech writer Zofka Kveder, followed by novel or long story "A Wondrous Story" by Mara Ivančan and finally, collection of short stories by Mara Švel-Gamiršek "The Portraits of Unknown Women". This work will answer the question whether the above mentioned authors offered a different image of the body then the one attributed to them as subordinated members

\footnotetext{
* Kornelija Kuvač-Levačić, PhD, Assoc. Prof., University of Zadar, Department of Croatian and Slavic Studies, Division of Croatian Language and Literature; Address: Obala kralja Petra Krešimira IV., HR-23000 Zadar, Croatia; E-mail: klevac@unizd.hr.

* Ana Vulelija, mag. philol. croat., University of Zadar, Department of Croatian and Slavic Studies, Division of Croatian Language and Literature; Address: Obala kralja Petra Krešimira IV., HR-23000 Zadar, Croatia; E-mail: avulelija@unizd.hr.
} 
of society (the woman's body, which as such cannot be related to the categories of the mind/spiritual because it is guided solely by impulses) and to the one offered by the second wave feminist theory several decades later (where the body is predominantly conceived as a material experience and which, as such, does not open the possibility to enter transcendence).

Key words: ontological body, touch, female Croatian writers, personal vision of the body, espacement.

(na engl. prev. Dorijana Deželić) 